\title{
Accumulation of Anthocyanins: An Aadaptive Feature in Sugarcane Leaf Under Cold Stress
}

\section{Archana $^{1}$, Sewa Ram ${ }^{2}$ and Viresh Singh ${ }^{3}$}

\author{
${ }^{1}$ Scientific officer, Div. of Plant Physiology, Sugarcane Research Center, Muzaffarnagar, 225001, UP, India \\ ${ }^{2}$ Senior Scientific Assistant, Div. of Plant Physiology, Sugarcane Research Center, Muzaffarnagar, 225001, UP, India \\ ${ }^{3}$ Joint Director, Sugarcane Research Center, Muzaffarnagar, 225001, UP, India
}

Author for Correspondence: Email-drarchanakumar14@gmail.com Mobile: +91-7017585961

Received: 20 October 2020/Accepted: 25 November 2020

URL:https://doi.org/10.38112/agw.2020.v08i02.003

\begin{abstract}
Sugarcane cultivated over more than five million hectare area in the world. Uttar Pradesh in the Subtropical region of India is an important sugarcane growing zone. The anthocyanin accumulation may protect sugarcane plants to oxidative damage during winter season and imperative resistance to cold. It also mitigates photo oxidative injury in leaves by efficiently scavenging free radicals and reactive oxygen species.

The studies were made using twelve popular sugarcane varieties i.e. CoSe 12232, CoSe 11453, CoS 08272, UP 05125, CoS 08276, CoS 767, Co 0238, Co 05011, CoSe 01434, CoS 08279, CoSe 03234 and CoS 8436 were planted under natural condition at Sugarcane Research center Muzafferanagar during 2015-17 and 2016-18 in autumn planting and evaluated for anthocynin contents during winter season. LTM leaf were used in determine the anthocynin contents during winter season in the month of January 2 nd week for both the year when average minimum temperature was $2.8^{\circ} \mathrm{C}$ in both year. Higher anthocyanin accumulation ( O.D above then $1.00 \mu \mathrm{gm} / \mathrm{gm}$ ) was observed in Co 0238,CoS 08279, CoSe 03234 and Co 05011 . The sucrose \% in juice and NMC/ha was also higher in theses varieties as compare to other tested varieties. The TAC (total anthocynin contents) is above $1.00 \mu \mathrm{gm} / \mathrm{gm}$ of leaf tissues be considered in possesses hardness against the cold injury.

Hence, the study concluded theses three varieties having maximum tolerance to low temperature and may be recommended for cultivation under winter atmospheric temperature.
\end{abstract}

Keywords: Sugarcane, Low temperature stress and Anthocyanin

\section{Introduction}

India has known as the original home of sugarcane and sugar. Sugarcane (Saccharum officinarum L.) is a widely grown cash crop in India responsible for the overall socio-economic development of the farming community and main feedstock for sugar production and it is cultivate about 5.2 (FAOSTATE 2019-20) million hectare area in the world. Uttar Pradesh is an important sugarcane growing belt of India with 119 working sugar mills, and 118.22 lack tones sugar production with $11.34 \%$ sugar recovery. In subtropical region, it occupies around 56 percent of total area and western part of Uttar Pradesh attain premier position regarding production sugar recovery and cultivation of sugarcane both but the cold condition is major constraints for productivity. Low temperature stress is considered the main course of plant growth constraints and crop yield reduction (Jin et.al.
2017, Sun et. al. 2018). Low temperature stress can damage the photosynthetic apparatus and reduce photosynthetic efficiency (Young et al 2016) induce oxidative stress and lead to the generation of reactive oxygen species (ROS) in tissues reduce the fluidity of membranes (Gusta and Wisneiwshai 2013). Berry and Bjorkman (1980) has been reported the temperature affects plant photosynthesis, Castro (2002) says low temperature lead to a rapid decline in photosynthetic efficiency, and high levels of sugar are not retained the low temperatures affect the development of the stalk, sugar transport and storage, leading to accumulation of sucrose in the leaves.

It was notice that during last five year in western Uttar Pradesh the mercury falling $0^{\circ} \mathrm{c}$ in the last week of December to last week of January. Due to this situation tillering is badly affected due to severe cold condition in autumn planting sugarcane. In autumn planting, due to 
prolonged low temperature stress leading to suppression of growth until onset of favourable temperature. It may be affects quality and quantity of sugarcane crop. The accumulation of non-enzymatic substances such as anthocyanins, phenlypropanoids, and terpenoids increases antioxidants capabilities there by reducing oxidative stress caused by low temperature, according to Arnholdt-Schmitt et al 2006, Sivankalyani et al 2016. Anthocyanin has been implicated in tolerance to stresses like drought, UV-B and heavy metals as well as resistance to herbivores and pathogens (Krupa et.al. 1996, Chalker-Scott 2002, Close and Beadle 2003). Anthocyanin is associated with enhanced resistance to chilling and freezing, heavy metals contamination, desiccation and to wounding (Close and Beadle 2003). Dong et al. (2018) suggested that anthocyanin is also considered as stress indicator due to their involvement in the response to many stress including high light and low temperature. According to Singh (1987) and Jain et. al. (2007) in subtropical India low temperature stress serves as a severe constrains, limiting the productivity of sugarcane through bud injury, poor stubble sprouting and deterioration in juice quality.

Sugarcane also contains anthocyanins. Many previous studies were focused on the development of methods for extraction and determination of total anthocyanins (Li et.al. 2011). At sugarcane Research Canter Muzaffernagar the temperature in the month of last week of December to second week of January (Approximate 12 days) observed below $2{ }^{\circ} \mathrm{C}$ during last five years. So, keeping this climatic situation the studies were made using 12 popular sugarcane varieties, planted under natural condition at Sugarcane Research centre Muzaffernagar during 2015-17 and 2016-18 in autumn season and evaluated the anthocyanin accumulation in planted varieties. The aim of this study to investigate the mechanisms of photosynthesis change in sugarcane leaves and other physiological parameters to affects the low temperature on sugarcane crop and also development of cold tolerance varieties is only solution to save the crop in low temperature stress. In this study we present our preliminary findings which may be useful for screen out low temperature tolerance varieties of sugarcane cultivation under winter atmospheric temperature as an indication to impart resistance to cold stress and tolerate oxidative damage during winter season in the western Uttar Pradesh.

\section{Materials and Methods}

Twelve popular sugarcane varieties both early and mid late maturing viz; CoSe12232, CoSe11453,
CoS08272, UP05125, CoS08276, CoS767, Co0238, Co05011, CoSe01434, CoS08279, CoSe03234 and CoS8436, were planted in randomized block design with three replications under autumn planting season in three rows of 6 meter length with $90 \mathrm{~cm}$ spacing between rows. Two budded setts and fertilizer dose was applied as per recommendation and conduct cultural operations. The data regarding germination percent, number and area of green leaves, plastrochron (day's leaf ${ }^{-1}$ ), qualitative and quantitative parameters were recorded with as per recommendation. LTM (Last transverse mark) leave was used to determine the anthocyanin accumulation contents during 2nd week of January for both the years when the average minimum temperature was $2.8^{\circ} \mathrm{C}$. Anthocyanin content was determined Hughes et al (2007), $0.5 \mathrm{gm}$ of fresh leave tissues and homogenized in $5 \mathrm{ml}$ of $80 \%$ methanol (acidified with $0.1 \% \mathrm{HCL}$ ). The homogenate was them centrifuged at $10000 \mathrm{rpm}$ for $30 \mathrm{~min}$. at $4^{\circ} \mathrm{C}$ and anthocyanin content was measured directly by absorbance of the supernatant at $525 \mathrm{~nm}$. Wave length was measured by UV-VIS spectrophotometer. The chlorophyll was extracted from $0.05 \mathrm{~g}$ leaves in $4 \mathrm{ml}$ of an $80 \%$ acetone solution at $4^{\circ} \mathrm{C}$ in the dark for 24 hours. The absorbance of chlorophyll extracts was recorded using UV-VIS spectrophotometer and the chlorophyll was calculated by the method of Wellborn (1994).

\section{Results and Discussion}

Level of anthocyanin accumulation varied in all tested varieties ranged between 0.84 to $1.510 \mu \mathrm{gm} / \mathrm{gm}$ of leave tissue. Higher anthocyanin accumulation was observed in varieties CoSe 08279, CoSe 03234, Co 0238 and Co 05011 i.e. $1.510,1.180,1.020$ and $1.12 \mu \mathrm{gm} / \mathrm{gm}$ of leaf tissues respectively (Table no 2). The yield $\mathrm{mt} / \mathrm{ha}$ were higher i.e. 94.91 in Co 0238, 89.99 in CoS 08279, 88.28 in CoSe 03234 and $87.06 \mathrm{mt} / \mathrm{ha}$ in Co 05011 with higher juice percent i.e. 17.61, 16.87, 17.20 and 17.00 respectively (Table no 1 ). The TAC (total anthocyanin contents) is above $1.00 \mu \mathrm{gm} / \mathrm{gm}$ of leaf tissues be considered in possesses hardness against the cold injury and studies have shown that low temperature can induce anthocyanin formation. Li et al 2017b, Carmona et al 2017 also reported the low temperature can induce anthocyanin formation. It may be stated the variety CoSe $08279, \mathrm{CoSe}$ 03234, Co 0238 and Co 05011 may be associated with an good accumulation of anthocyanin as compare to other tested varieties, which increases the ability for survival under very low temperature conditions while variety CoSe 11453, $\operatorname{CoS} 08272$, and $\operatorname{CoS} 08276$ the differences in 
anthocyanin content was almost negligible in low temperature. The result of pooled data indicated that autumn planting sugarcane accumulated anthocyanins pigments during winter season when the temperature decreased 50C (2-50C) which might have protected their photo system from adverse effects due to low temperature. The significance of anthocyanin accumulation in response to low temperature stress has been reported in crops other than sugarcane by several workers viz; Gloud et al 2000, Steyn et al 2002, McKnown et al 1996). In this study higher increase in anthocyanin content in the second week of January may be due to continuous low temperature for longer period. The Plastocrone (days leaf-1), (Table no 2) sucrose $\%$ in juice and NMC/ha (Table no 1 ) was also higher in theses varieties as compare to other tested varieties, but total chlorophyll contents in leaf being more during pre-winter $(5-100 \mathrm{C})$ and decline in winter season with the increases of anthocyanin pigment. Close and Beadle (2003), reported significant reduction in chlorophyll and carotenoids contents in sugarcane varieties during winter season. So we can say the anthocyanin and formation of chlorophylls in leaves has negative correlated, it means anthocyanin accumulation increase then chlorophyll is decreased. Radha Jain and Sangeeta Srivastava (2017) also reported the sugarcane genotype Co 1148 showed highest anthocyanin content which indicates that it is suitable as breeding material for developing sugarcane genotypes tolerance to cold stress. Dong et.al. (2018), Schulz et. al. (2016) also reported also anthocyanin considered as stress indicators due to their involvements in the response to many stress as high light and low temperature.

These results suggest that anthocyanin can improve plant tolerance to and better perform under low temperature. Lorence-Kukula et al (2005), Zang et al (2016), Sivankalayani et al (2016), and Liu et al (2018) also suggested that anthocyanins in $\mathrm{M}$. micrantha leaves were more likely to have antioxidant effects in winter. Hence, the greater accumulation of anthocyanin pigments in CoSe 08279, Co 0238, Co 05011, and CoSe 03234 during winter season resulted higher rate of metabolic activities to crop with low temperature stress. The study concluded theses four varieties having maximum tolerance to low temperature and may be recommended for cultivation under winter atmospheric temperature and suitable as breeding purpose for developing sugarcane varieties tolerant to cold stress which is one of the limiting factors in sugarcane cultivation.
Table: 1 Qualitative and Quantitative characters of sugarcane varieties

\begin{tabular}{l|l|l|l|l|l}
\hline $\begin{array}{c}\text { SI. } \\
\text { No. }\end{array}$ & $\begin{array}{c}\text { Varietie } \\
\mathbf{S}\end{array}$ & $\begin{array}{c}\text { Germin } \\
\mathbf{a t i o n} \\
\mathbf{( \% )}\end{array}$ & $\begin{array}{c}\text { NMC/ha } \\
\mathbf{( 0 0 0 )}\end{array}$ & $\begin{array}{c}\text { Sucrose } \\
\mathbf{\%} \text { in } \\
\text { juice }\end{array}$ & $\begin{array}{c}\text { Yield } \\
\mathbf{m t} / \mathbf{h a}\end{array}$ \\
\hline 1 & $\begin{array}{l}\text { CoSe } \\
12232\end{array}$ & 43.44 & 166 & 16.31 & 71.53 \\
\hline 2 & $\begin{array}{l}\text { CoSe } \\
11453\end{array}$ & 59.50 & 159 & 16.07 & 70.01 \\
\hline 3 & $\begin{array}{l}\text { CoS } \\
08272\end{array}$ & 45.15 & 126 & 16.94 & 60.19 \\
\hline 4 & UP 05125 & 51.11 & 148 & 16.24 & 83.96 \\
\hline 5 & $\begin{array}{l}\text { CoS } \\
08276\end{array}$ & 55.50 & 141 & 16.30 & 80.41 \\
\hline 6 & CoS 767 & 51.72 & 139 & 15.28 & 78.55 \\
\hline 7 & Co 0238 & 57.53 & 171 & 17.61 & 94.91 \\
\hline 8 & Co 05011 & 55.00 & 155 & 16.89 & 87.06 \\
\hline 9 & $\begin{array}{l}\text { CoSe } \\
01434\end{array}$ & 61.28 & 154 & 15.03 & 84.33 \\
\hline 10 & $\begin{array}{l}\text { CoS } \\
08279\end{array}$ & 56.44 & 189 & 16.27 & 89.99 \\
\hline 11 & $\begin{array}{l}\text { CoSe } \\
03234\end{array}$ & 58.61 & 164 & 16.86 & 88.28 \\
\hline 12 & CoS 8436 & 48.28 & 124 & 15.51 & 65.28 \\
\hline & $\begin{array}{l}\text { C.V. } \\
\text { C.D. }\end{array}$ & 11.129 & 3.482 & 3.181 & 4.672 \\
\hline & 10.156 & 7822.311 & 0.421 & 6.351 \\
\hline
\end{tabular}

Table:2 Biochemical characters of sugarcane varieties

\begin{tabular}{|c|c|c|c|c|}
\hline $\begin{array}{l}\text { Sl. } \\
\text { No. }\end{array}$ & Varieties & $\begin{array}{l}\text { Anthocyanin } \\
\text { accumulation } \\
\text { (absorbance at } \\
525 \mu \mathrm{m} / \mathrm{g} \\
\text { fresh tissue) }\end{array}$ & $\begin{array}{l}\text { Total } \\
\text { Chlorophy } \\
11 \quad \text { (mg/g } \\
\text { fresh leaf) }\end{array}$ & $\begin{array}{l}\text { Plastochron } \\
\text { (days leaf }^{-1)}\end{array}$ \\
\hline 1 & CoSe 12232 & 0.91 & 1.45 & 3.92 \\
\hline 2 & CoSe 11453 & 0.81 & 1.36 & 3.59 \\
\hline 3 & CoS 08272 & 1.10 & 1.00 & 3.98 \\
\hline 4 & UP 05125 & 0.78 & 1.56 & 3.52 \\
\hline 5 & CoS 08276 & 0.88 & 1.40 & 3.78 \\
\hline 6 & $\operatorname{CoS} 767$ & 0.99 & 1.56 & 3.60 \\
\hline 7 & Co 0238 & 1.02 & 1.17 & 3.78 \\
\hline 8 & Co 05011 & 1.12 & 0.75 & 3.96 \\
\hline 9 & CoSe 01434 & 1.18 & 2.18 & 3.92 \\
\hline 10 & CoS 08279 & 1.51 & 1.32 & 4.12 \\
\hline 11 & CoSe 03234 & 1.18 & 0.89 & 4.21 \\
\hline \multirow[t]{3}{*}{12} & CoS 8436 & 1.41 & 0.74 & 3.10 \\
\hline & C.V. & 10.788 & 5.310 & 1.8733 \\
\hline & C.D. & 0.146 & 0.142 & 0.123 \\
\hline
\end{tabular}




\section{References}

Arnholdt-Schmitt B, Costa, J H and de melo, D.F. 2016. AOX-A functional marker for efficient cell reprogramming under stress, Trends Plant Sci, 11, 281-287. Doi: 10.1016/J. Tplants 2006.05.001.

Berry J. And Bjorkman O.1980. Photosynthesis response and adaptation to temperature in higher plants. Annual review of plant physiology: 31, 491-543.

Chalker-Scott L. 2002 Do anthocyanin function as osmo-regulators in leaves tissues \$ In: Gould K.S. Lee D.W. (Eds) Anthocynins in leaves Amsterdam : Academic Press: Advances in Botanical Research , 37: 103-27.

Close D.C. and Beadle C.L. 2003. the eco-physiology of foliar anthocyanin. Bot. Rev. 69 (2) : 149-61.

Carmona L, Alquezar B marques, V V and Pena L. 2017. Anthocyanin biosynthesis and accumulation in blood orange during postharvest storage at different temperature. Food Chem. 237, 7-14.

Castro P R C. 2002. Efeitos da luminosidade e da temperatura na fotossíntese e produção eacúmulo de sacarose e amido na cana-de-açúcar. STAB. Açúcar, Álcool e Subprodutos, Vol.20, No. 5, pp. 32-33, ISSN 0102-1214Carmona. L., B., Marques, V.V.

Dong Y, Qu Y, Qi R, Bai X, Tian G Wag Y. J and Zhang K. 2018. Transcriptase analysis of the biosynthesis of anthocyanin in Begonia semi perflorens under low temperature and high light conditions Forest, 9 (2) 87, Doi 10.390/F .9020087.

Gloud K S, Markham K R, Smith R.H, and Goris J J 2000. Functional role of anthocynin in the leaves of Quintinia serrata A. Cunn. J. Exp Bot. 51 (347): 1107-15.

Gusta, L V and Wisneiwski M. 2013. Understudying the plant cold hardness : an opinion. Physio, plant, 147, 4-14 doi: 10.1111/j.1399-3054.2012.016111x.

Huges, N M Morley, B and Smith W.K. 2007. Coordination of anthocyanins in plant decline and photosynthetic maturation in juvenile leaves of three deciduous tree species. New phytol. 175,675-685.

Jain, R Srivastava A K Solomon, S Yadav, R L 2007. Low temperature induced biochemical changes affects the stubble bud sprouting in sugarcane (Saccharum Spp. hybreds) Plant Growth Regul. 53, 17-23.

Jin R, Kim B, H Ji C, V, Kim 2017. Over expressing IbCBF3 increases low temperature and drought stress tolerance in transgenic Sweet potato, Plant Physio Biochem. 118, 45-54.

Krupa Z, Baranowska M, and Orzol D 1996. Can anthocyanin be considered as heavy metal stress indicator in higher plants $\$$ Acta Physiology Plant arum, 18 (2) : 147-51.

Li X, Song H, S Jia, C Yang, Y Zhu W, 2011. Quantitative analysed and recovery optimization of flavonoids and anthocyanin in sugar-making processes of sugar industry. Food Chem. 125, 150-157.

Li, Y.,Tikunov, Y., Schoute, R.E. Marcelie,L.F. M. Visser, RGF. And Bovy, A. 2018 anthocyanins biosynthesis and degredatio machanisims in solanaceous vegetables: a review. Front. Chem.. 6. 52,
Li J, Li Y,Yin Z, Jiang, J Zhang and M Guo. 2017b. The Araidopsis UDP-glcosyl transferees UGT79b2 and UGT79b3, contribute to cold salt and drought tress tolerance viz moduling anthocyanin accumulation. Plant.j. 89, 85-103 doi: $10.1111 /$ tpj. 13324

Lorence-akukula, K Jafra, S Oszmianski, J And Szopa J. 2005 Ectopic expression of anthocyanin 5-o- glucosyltransferase in potato tuber cause increased resistance to acteriaJ. Agric. Food. Chem . 53,272-781. Doi: 10.1021/jfo48449p)

Liu Y, Tikunov Y, Schouten R E Marcelie, L F M Visser RGF and ivy A. 2018 Anthocyanin and biodegradation mechanisms in solanceous vegetales: a review. FrontChem. 6, 52 ddddoi: 10.3389/fchem. 2018.00052.

Mc Known R, Kuroki G and Warren G 1996 .Cold responses of Arabidopsis mutants impaired in freezing tolerance. J Exp. Bot., 47 (305) ; 1919-25.

Radha Jain and Sangeeta Srivastava 2017 .Genetic variation for anthocynin content in sugarcane genotypes during winter season, Indian Journal of Sugarcane Technology 32 (02): 95-97 December 2017.

Sun L, Li Wang, Z Sun, Z Zhu, X Liu, and J Set 2018. Cold priming induce tolerance to subsequent low temperature stress is enhanced by melatonin application during recovery in Wheat. Molecules 23, 1091. Doi., 10.3390 / molecules 23051091

Singh O. and Kanwar RS 1978. Physiological evolution of germplasm for frost resistance, Int. Sug. J.80; 139-141.

Singh O.1984. Principal sugars of Juice in relation to frost hardness of sugarcane. 48th sugarcane technology association part 1. Ag 91- Ag 94.

Singh A. 1987, Physiological basis for varietal improvement under stress environment in sugarcane. In. K.Mohan Naidu, T.V. Srenivasan and Premchanedran (eds) Sugarcane varietal improvement, SBI Coimbatore, pp 57-82.

Sivankalyani V, Feygenerg, O Diskin, S Wright, B and Alkan N. 2016. Increased anthocyanins and flavonoids in mango fruit peel are associated with cold and pathogen resistance. Postharvest Biol. Technol. 111, 132-139. Doi"10.1016/j postharvest bio . 2015.08.001.

Steyn W, J Wand S J E Holccroft D M and Jacobs G. 2002 Anthocyanins in vegetative tissues: A proposed unfiled function in photo protection, New Physiology 155 .3:349-61.)

Schulz E Takayuki T Ellen Z Alisdair R F and Drik K H 2016. Flavonoids are determinants of freezing tolerance and cold acclimation in Arabidopsis thaliana. Sci. Report, 6: 34027. DOI : 10.1038/srep34027

Welblurn A R 1994. The spectral determination of chlorophyll a and $\mathrm{b}$, as well as total arotenoids, using various solvents with spectrophotometer of different resolution. J. Plant. Physiology. 144, 307-313. Doi: 10.1016/SO176-1617 (11) 81192-2.

Yang S L, Lan S S, Deng F F and Gong M 2016. Effect of calcium and calmodulin antagonists on chilling stress-induced proline accumulation of Jatropha curcus L. J. Plant Growth Regul. 35, 815-826. Doi: 10.1007-s00344-016-9584-3.

Zhang J, Chow WS Liu, X T Zhang, P Liu N and Peng C L 2016. A magic red coat on the surface of young leaves : anthocyanin distributed in trichome layer protect Castanopsis fissa leaves from photoinhibition. Tree Physiol. 36. 1296-1306. 